\title{
THE CURATIVE ROLE OF BITUMEN IN TRADITIONAL PERSIAN MEDICINE
}

\author{
LJEKOVITA ULOGA BITUMENA U \\ TRADICIONALNOJ PERZIJSKOJ MEDICINI
}

\author{
Mahdi Shahriari", Farzaneh Zare ${ }^{* *}$, Majid Nimrouzi ${ }^{* * *}$
}

\begin{abstract}
SUMMARY
Aim: Bitumen is a natural substance effusing from rocks' notches in some highland areas; it has been known as an effective remedy for treating some illnesses. Considering pain relieving properties of bitumen in traditional Persian medicine (TPM) sources, this study aims to review the viewpoints of TPM sages regarding bitumen in the context of traditional Persian medicine. It also provides applicable information for interested researchers to conduct well-designed clinical trials and evaluate therapeutic effects of bitumen claimed in TPM sources.

Material and method: Various databases including Embase, SID, IRANDOC, IranMedex, Scopus and PubMed were searched with keywords "bitumen" and "Shilajit". Furthermore, main traditional Persian medicine sources including Avicenna's "Canon of medicine", "Continens Liber" by Razes, "The storehouse of medicaments" by Aghili, "Gift for the faithful" by Momen Tonekaboni and "Measure for medicine" written by Muhammad Akbar Shah Arzani were reviewed with Persian keywords "Moomiaii" and "Mumnaei".

* Department of Pediatrics, Hematology-Oncology Branch, Shiraz University of Medical Sciences, Shiraz, Iran.

** Research Center for Traditional Medicine and History of Medicine, Shiraz University of Medical Sciences, Shiraz, Iran.

*** Research Center of Quran, Hadith and Medicine, Shiraz University of Medical Sciences, Shiraz, Iran. / Department of Traditional Persian Medicine, School of Traditional Medicine, Shiraz University of Medical Sciences, Shiraz, Iran.

Correspondence Address: Majid Nimrouzi, Department of Traditional Persian Medicine, School of Traditional Medicine, Shiraz University of Medical Sciences, Zand Street, 71397-48479 Shiraz, Iran. E-mail: nimruzim@sums.ac.ir.
\end{abstract}


Results: According to TPM sources, bitumen was used by Iranian's physicians to treat a wide range of diseases. It was known especially as an effective remedy to improve gastrointestinal digestive problems.

Conclusion: Bitumen is cited in traditional Persian medicine sources as an effective remedy for treatment of a wide range of diseases, especially GI disorders and bone pain. Recent studies showed the beneficial effects of bitumen in treatment of wound healing, however using it in medical practice for other health dilemma should be confirmed by conducting well-designed clinical studies in the future.

Keywords: Bitumen, Shilajit, Traditional Persian Medicine, Complementary medicine

\section{INTRODUCTION}

Bitumen, mountain perspiration, momenaii in regional dialect, is a semi-solid brown to black colored effusion, which is a result of oxidation of petroleum hydrocarbons and crushes in the earth layers in vicinity of underground oil reserves and also some caves (I). It was commonly used in Europe between the $\mathrm{I} 2^{\text {th }}$ and $\mathrm{I} 7^{\text {th }}$ centuries (2). Chemical analysis of bitumen showed the presence of calcium ions, phosphates, magnesium carbonate, sulfur, oxygen, nitrogen and molecules such as polysaccharide (I). According to parole of some traditional healers, bitumen originated from some herbal medicines which were trapped between stones slots for a long time and flowed through crevices following gradual fermentation (2). It is also known as Dead Sea asphalt, a variant of bitumen found in the seabed, which was considered as a possible indicator of petroleum in that region in past times (3).

Moomiaii is a Persian word, derived from müm (wax), which also addresses mineral pitch, bitumen (2), momenayi, momeney, moomian (4) momie (5) in other traditional sources. Razes cited bitumen as abdaroo (healing water) in

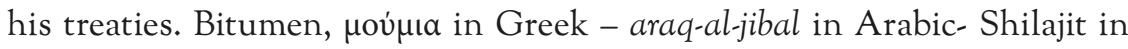
Hindi, means "conqueror of mountains" in Sanskrit (6) and "rock juice" in Tibet (7), however, according to recent evidence, bitumen used as an herbal remedy is different from resins - mummy - that Egyptians used for embalming. These two substances were similar just in shape, viscosity and color (3). Dawson mentioned that bitumen (mummy) was used as an herbal remedy in ancient worlds and Egyptians used it for the first time for embalming of the human bodies. Over the course of time, the association between bitumen as an herbal remedy and mummy as mummification's material of dead human bodies was gradually lost and it was generally applied to medicated flesh (2).

Bitumen, in the traditional Persian medicine (TPM) sources, is a known herbal remedy with many medical properties. Medieval Persian physicians 
prescribed bitumen as poultice to accelerate bone fracture reunion and repair, and syrup to alleviate GI problems, respiratory diseases and physical disabilities. Bitumen was frequently cited as a safe curative agent in TPM sources; however evidence of its medicinal properties is scarce. Although various studies showed safely use of bitumen as a beneficial herbal medicine (8), probable fungal contamination producing lethal mycotoxins necessitates the importance of isolation of its active constituents and formulation of bitumen for widespread use (9). Herein, authors aimed to review literature and TPM main sources to open a new window for interested researchers tailoring well-designed clinical trials to confirm safety and efficacy of bitumen in treatment of claimed issues in TPM.

\section{MethoD}

Main databases, such as PubMed, Scopus, Embase, IRANDOC, IranMedex and SID were searched with keywords "Traditional Persian medicine", "Complementary medicine", "Shilajit", "Bitumen", "Asphaltum", "Mineral pitch", "Jews pitch" and "Asphalt", and also TPM sources including Rhazes' (854-925 CE; Rey, Iran) "Al-Havi" (Continens Liber) and "Al-Mansoori Fi-al-teb" (Io), Avicenna's (980-1037 CE) Canon of Medicine, "Makhzanal-Advieh" (The storehouse of medicaments) by Aghili (I689-I79I CE) (II), "Tohfat-al-momenin" (Gift for the faithful) by Momen Tonekaboni (r2), "Mizan al-teb" (Measure for medicine) by Muhammad Akbar Shah Arzani (1722/Ir34) (r8th century) (r3) with Persian keywords "Moomiaii" and "Mumnaei".

\section{History}

Bitumen was used as a preservative for thousands of years. Egyptians, seemingly, were the first people who used bitumen for corpse preservation and as a remedy to treat some illnesses (I4). Hakim Momen, in "Tohfat-almomenin", cited that Aristoteles ( 384 BC-322 BC) knew about the medicinal properties of bitumen and prescribed it for treating patients (I2).

Iranians also knew bitumen and used it as a remedy for some diseases, but it seems like a chapter about that was excluded from their books and treaties. Khajeh- Nassir-al-din-Toossi in Tanksuq-Nameh (Book of Valuable Information) (5) and Aghili in Makhzan-al-Advieh allotted a separate section for identification of bitumen and its properties $(5, \mathrm{II})$. Furthermore, other Iranian physicians, up to recent years, have done some researches that guide us to a comprehensive data about bitumen and its features. 


\section{BitUMEN AS A REMEDY IN TPM}

According to the TPM approach and theory of humoral pathology, foods and medicines induce a mizaj (dual quality) in the body after consumption (15, I6). It includes an active (hotness/coldness) and passive (wetness/dryness) component $(\mathrm{I} 7)$. Accordingly, bitumen is a hot-dry medicine, tender and with dissolvent properties (4). The best quality bitumen is black, shiny and non-fetid. Bitumen is used both orally and locally as poultice, however, its syrup is more effective by and large (I2).

Bitumen alleviates diseases with internal causes due to its heating and healing properties (Table I). It is a tonic, exhilarating aphrodisiac, solvent of cold-causing substances, ablative of body moistures, and it is also an effective remedy for tremor and facial palsy (го). Bitumen is a tonic substance which enlivens the heart and strengthens stamina (I2). It also causes weight gain due to improving digestion and food absorption in GI tract (I2) in emaciated patients, and maintains health (I2). Consumption of bitumen with iris (Iris florentina L.), decoction of mint (Mentha Spicata L.) and oxymel (syrup of honey and vinegar) alleviates palpitation (I2, I8). Bitumen is also proposed for the treatment of some infectious viral diseases. Poultices of bitumen with rose flower (Rosa damascena) are effective in the treatment of chickenpox (rg).

\section{Central nervous system}

Bitumen is a tonic of main organs ) andam-e-raisseh(, that is, brain, liver and heart (20). Using a compound of bitumen and lily (Lilium candidum L.) oil as nasal drops has been mentioned as a beneficial remedy for chronic headaches (Io). Snuffing mixture of bitumen and habbah-al-khazraa (Pistacia atlantica) oil is also helpful for chronic headache (2I). Sodden of marjoram (Origanum majora$n a L$.) and bitumen might be a helpful remedy for headaches and epilepsy with cold-causes $(4$, I2 $)$. Tremor of old ages because of cold induced causes would be alleviated with bitumen (20). Oral use and external use of bitumen ameliorate the symptoms of patients suffering from facial palsy (2I). Nasal drops of marjoram and bitumen are also helpful for simple headache and headache due to phlegm humor as well as facial palsy, paralysis due to stroke and vertigo (Io). Melon (Cucumis melo) seed extract and bitumen may treat epistaxis (I2, 2I).

\section{Gastrointestinal tract}

Bitumen soaked in decoction of celery (Apium graveolens) seed is helpful in curing hiccup (2I) and with water-honey as a remedy for halitosis (I2). Bitumen is a digestive aid and GI tonic. It also helps healing process of liver inflammation after trauma (19). 
Table I. Different usage forms of bitumen for prescription in different body organs.

\begin{tabular}{|c|c|c|c|}
\hline & Disease & Escort compounds & Route \\
\hline & $\begin{array}{l}\text { Inflammation of } \\
\text { mouth }\end{array}$ & Mulberry (Morus nigra L.) Sauce (I2) & Gargling \\
\hline \multirow[t]{5}{*}{ ENT } & Deafness & Simple (20) & External \\
\hline & Ear ache & $\begin{array}{c}\text { Simple (20) } \\
\text { Jasmine (Jasminum L.) oil (I8, 2I })\end{array}$ & External \\
\hline & tongue tie & $\begin{array}{l}\text { Decoction of Zataria Multiflora (I8) or } \\
\text { savory (Satureja L.) (2I) }\end{array}$ & Oral \\
\hline & tongue tie & $\begin{array}{c}\text { Strawberry (Fragaria ananassa) Sauce - } \\
\text { Sweet pomegranate (Punica granatum L.) } \\
\text { sauce (I2) }\end{array}$ & Gargling \\
\hline & $\begin{array}{l}\text { Otitis media } \\
\text { (purulent) }\end{array}$ & $\begin{array}{l}\text { Rose oil and water of unripe grape - } \\
\text { Verjuice - (Vitis vinifera L.) (r8) }\end{array}$ & $\begin{array}{c}\text { External } \\
\text { (Cotton } \\
\text { soaked in rose } \\
\text { oil and rose } \\
\text { verjuice) }\end{array}$ \\
\hline \multirow[t]{2}{*}{ GI } & Flatulence & Trachyspermum ammi (I8) & Oral \\
\hline & Hemorrhoid & Simple (20) & External \\
\hline \multirow[t]{3}{*}{ Lung } & $\begin{array}{l}\text { Productive cough } \\
\quad \text { (wet cough) }\end{array}$ & $\begin{array}{c}\text { Cordia Myxa } \\
\text { Jujube (Ziziphus jujuba) soaked in water } \\
\text { or non-alcoholic beer (I8) }\end{array}$ & Oral \\
\hline & Hemoptysis & Goat leg broth and yolk (2I) & enema \\
\hline & $\begin{array}{l}\text { Enuresis and } \\
\text { frequency }\end{array}$ & Iris (Iris germanica L.) oil (4) & $\begin{array}{l}\text { External } \\
\text {-drippling } \\
\text { in urethral } \\
\text { meatus }\end{array}$ \\
\hline \multirow[t]{2}{*}{ GU } & Renal stone & Simple (20) & External \\
\hline & Impotence & $\begin{array}{l}\text { Flour (2I) or milk (I2), coconut or walnut } \\
\text { oil (I2) }\end{array}$ & \\
\hline
\end{tabular}

Armenian soil with saffron soaked in gooseberry (Ribes uva-crispa) water or golden rain tree (Cassia fistula) water was considered an effective remedy for liver and GI diseases as well as nausea due to accumulation of phlegm in stomach. Bitumen soaked in decoction of some herbal medicines such as Zenian (Trachyspermum ammi), Zireh-ye-sabz (Cuminum cyminum) and Zirehye-siah (Carum carvi) strengthens the stomach and ameliorate flatulence ( $\mathrm{I} 8$, 2I). Patients with bloody diarrhea or intestinal ulcers may take advantage of bitumen (I2, I9). Poultices of bitumen have been prescribed for hernia and edema due to liver disease (I2).

It is also mentioned as a beneficial remedy for early stages of hernia in children which aggravates by crying, if it is used in the form of mixture 
with Oak apple (Quercus garryana), Gulnar (Punica granatum), Frankincense (Boswellia Roxb. ex Colebr), Beaver (Castor canadensis) testicle and Eremurus persicus in water of alum - zaak - (Steoptria-Alon-aloman-alen( (I2).

\section{Cardiopulmonary}

Bitumen boosts heart potency. Bitumen with jujube (Ziziphus vulgaris) is a remedy for cough (I2). If it is mixed with Sepestan (Cordia myxa) and non-alcoholic beer, it could improve purulent cough (ro). Bitumen and oxymel are used for the treatment of diphtheria (2I). Syrup of oxymel and celery (Apium graveolens) juice is a remedy for spleen diseases (I2). Leprosy, vitiligo, melasma and the first stage of elephantiasis may be cured with bitumen (rg).

\section{PoIsoning}

Bitumen is a helpful remedy for pain relief after snake or scorpion bite (I9). Bitumen added to chicory relieves snake bite; and it improves snake or scorpion bites locally and systemically, if it is mixed with cow butter or oil $(\mathrm{I} 2, \mathrm{I} 8)$.

\section{Fracture AND DisLocation}

Bitumen prevents post-trauma inflammation, swelling and accelerates scar healing. It is one of the best known poultices for a fracture of extremities, improves healing process and alleviates pain (I2). Drinking bitumen syrup and using bitumen poultice is a proper remedy for joint dislocation and ankle sprain (I2).

\section{WOUND HEALING}

Bitumen improves wound inflammation and accelerates wound healing. In the case of nerve or muscle tearing, local application of bitumen is effective for early tissue repair (I2). A Mixture of Terre sigillee (Teen-e-makhtoom) and bitumen is an effective wound healer (2I). It is also a useful remedy for repair of duodenal ulcer and intestinal erosive ulcers as mentioned by Rhazes (Io).

\section{Discussion}

Bitumen, an ancient remedy for vast range of diseases, has been recently considered a complementary therapy for acceleration of the healing processes in patients suffering trauma related fractures and scars. Despite its beneficial effects, claimed in traditional and folk medicine, and confirmed in-vivo antioxidant activity, the bioactivity of bitumen lacks consistent evidence (I). 
A probable mechanism of action of bitumen is its anti-inflammatory effects through mediating inflammation phase and accelerating healing process. The other mechanism might be improving oxygenation in wound area. Bahalo et al. found positive effects of bitumen and Vitamin E combination therapy on gentamicin induced nephrotoxicity probably through inhibition of lipid peroxidation (22). Bitumen contains high amount of fulvic acid, a strong antioxidant (23), which justifies its anti-inflammatory and healing property. "Wujinsan", herbal medicine containing fulvic and humic acids in Chinese medicine, showed significant anti-inflammatory and blood-coagulating effects $(7)$. Schepetkin et al., through fractionation of crude bitumen to fulvic acid, humic acid, humin and hymatomelanic acid, showed immunomodulatory effect of fulvic acid in murine splenic lymphocytes (24).

Bitumen also acts as an antibiotic which controls infection and facilitates wound healing. It is a barrier against external factors which can protect the wound in order to improve wound healing process (25). Bitumen showed in vitro complement-fixing activity, probably because of carboxylic group content of fulvic acid, may partly implicate its anti-inflammatory and anti-microbial properties (25). Although, poultice with bitumen showed no significant difference in histological criteria involved in wound healing, it accelerated wound healing, probably because of increasing collagen synthesis and improving scar tension resistance, that is a protective factor against scar tearing $(26,27)$. Recent studies revealed the beneficial effects of bitumen in acceleration of scar healing in mammals. Healing effect of bitumen has been proved in several recent studies in tibia fracture of pigeon, rabbit and rabbit's dermal scars (27, 28). Recent clinical trials also found the bone healing effects of bitumen in the patients suffering tibia and femoral fractures (29). Bitumen is similar to phenytoin in repairing scars. An experimental study on rats, comparing bitumen with phenytoin cream $\mathrm{I} \%$, showed antimicrobial activity of bitumen on pseudomonas aeruginosa, an important germ that is resistant to wide variety of antibiotics and chemical detergents (26). Oral prescription of bitumen improved ethanol induced gastric ulcers in rats (30).

Positive findings in experimental studies bridges a new way to effectiveness of bitumen in healing process in human, a notion that is in accordance with TPM sources. It includes chronic ulcers of diabetes as well as bed sores in debilitated patients hospitalized in ICUs and other centers of chronic patients' care. Despite the aforementioned beneficial effects, prescription of bitumen as an herbal remedy should be considered with precaution because of probable contamination with heavy metals and risk of poisoning (3I). 


\section{Conclusion}

Bitumen is a potential remedy which may be used as an alternative treatment in vast spectrum of diseases. Healing properties of bitumen have been proved according to several experimental studies; however, it is an incipient step to conduct vigorously-designed clinical trials to confirm former experimental studies as well as revealing beneficial medical effects of bitumen in other diseases. In addition to wound healing and antiaging properties mentioned in TPM sources, bitumen is a potent and safe remedy for many GI problems including duodenal ulcer, dyspepsia and hemorrhoids that can be a great field for future studies.

\section{BIBLIOGRAPHY}

1. Wilson, Eugene, G Victor Rajamanickam, G Prasad Dubey, Petra Klose, Frauke Musial, F Joyonto Saha, Thomas Rampp, Andreas Michalsen, and Gustav J Dobos. "Review on Shilajit Used in Traditional Indian Medicine." Journal of ethnopharmacology 136, no. 1 (2011): 1-9.

2. Dawson, Warren R. "Mummy as a Drug." Proceedings of the Royal Society of Medicine 21, no. 1 (1927): 34-39.

3. Nissenbaum, Arie. "Ancient and Modern Medicinal Applications of Dead Sea Asphalt (Bitumen)." Israel Journal of Earth Sciences 48, no. 3-4 (1999): 301-8.

4. Jorjani, Esmail. Zakhireye Kharazm Shahi (Treasure of Kharazm Shah) [in Persian]. 1 ed. Tehran: Iranian Medical Academy, 2001.

5. Toossi, Nasir al din Mohammad. Tansookh Nameh-E-Ilkhani, . Tehran: Research Institute for Islamic and Complementary Medicine (RICM).

6. Meena, Harsahay, HK Pandey, MC Arya, and Zakwan Ahmed. "Shilajit: A Panacea for High-Altitude Problems." International journal of Ayurveda research 1, no. 1 (2010): 37 .

7. Schepetkin, Igor, Andrei Khlebnikov, and Byoung Se Kwon. "Medical Drugs from Humus Matter: Focus on Mumie." Drug development research 57, no. 3 (2002): 140-59.

8. Velmurugan, C, B Vivek, E Wilson, T Bharathi, and T Sundaram. "Evaluation of Safety Profile of Black Shilajit after 91 Days Repeated Administration in Rats." Asian Pacific journal of tropical biomedicine 2, no. 3 (2012): 210-14.

9. Ghosal, Shibnath, Jawahar Lal, Sushil K Singh, Raj K Goel, Arun K Jaiswal, and Salil K Bhattacharya. "The Need for Formulation of Shilajit by Its Isolated Active Constituents." Phytotherapy research 5, no. 5 (1991): 211-16.

10. Razi, Zakaria. "Mansuri Fi-Al-Tib." Persian Translation (2008). 
11. Khorasani, MH Aghili. "Makhzan Al Advieh." Bavardaran Press. Research institute for Islamic and Complementary Medicine, Iran University of Medical Sciences, Tehran, Iran, 2001.

12. Hossaini-Tabib, MM. "Tohfe of Hakim Momen." Mostafavi Press, Tehran and Qum (In Persian), 1959.

13. Shāh Arzānī, MA. Mìzān Al-Tỉbb [in persian]. Qom: Ehyay-e-tabiei.

14. Hajar, Rachel. "The Air of History: Early Medicine to Galen (Part I)." Heart views: the official journal of the Gulf Heart Association 13, no. 3 (2012): 120.

15. Nimrouzi, Majid, Alireza salehi, Alireza Ahmadi, and Hossein Kiani. "Avicenna's Medical Didactic Poems: Urjuzeh Tebbi." AMHA - Acta MedicoHistorica Adriatica (2015).

16. Nimrouzi, M., and M. Zare. "Principles of Nutrition in Islamic and Traditional Persian Medicine.” J Evid Based Complementary Altern Med 19, no. 4 (Oct 2014): 267-70.

17. Nimrouzi, Majid, and Mohammad Mehdi Zarshenas. "Anorexia: Highlights in Traditional Persian Medicine and Conventional Medicine." Avicenna journal of phytomedicine 8, no. 1 (2018): 1.

18. Razi, M. "Al-Havi." International Academy of Medical Sciences, Tehran (2005).

19. Shirazi, Emad al Din Mahmod. Atashak. Tehran: Medical Sciences University of Iran, 2003.

20. Tabari, Ali Ibn Sahl. Ferdos Al Hekmah. 2 ed. Tehran: Chogan Press, 2013.

21. Razi, Baha al Doleh. Kholase Al Tajarob(New Version). Tehran: Medical Sciences University Tehran press, 2008.

22. Namjoo, Abdul Rasool, Hani Bahalo, Esfandiar Heidarian, and Ebrahim Rahimi. "Protective Effect of Mummy on Gentamicin Induced Nephrotoxicity in Rats." Journal of Mazandaran University of Medical Sciences 26, no. 135 (2016): $107-18$.

23. Carrasco-Gallardo, Carlos, Leonardo Guzmán, and Ricardo B Maccioni. "Shilajit: A Natural Phytocomplex with Potential Procognitive Activity." International Journal of Alzheimer's Disease 2012 (2012).

24. Schepetkin, Igor A, Andrei I Khlebnikov, Shin Young Ah, Sang B Woo, ChoonSoo Jeong, Olesya N Klubachuk, and Byoung S Kwon. "Characterization and Biological Activities of Humic Substances from Mumie." Journal of agricultural and food chemistry 51, no. 18 (2003): 5245-54.

25. Schepetkin, Igor A, Gang Xie, Mark A Jutila, and Mark T Quinn. "ComplementFixing Activity of Fulvic Acid from Shilajit and Other Natural Sources." Phytotherapy research 23, no. 3 (2009): 373-84.

26. Alah, Tavakoli M, Hadad M Khaksari, and Sh A Aasar. "Comparison of Topical Application of Mummify and Phenytoin Cream on Skin Wound Healing in Rat." (2003). 
27. Rezvanipour Mozaffar, Khatibi Hosain. "The Effect of Mummy on the Healing of Bone Fracture of Tibia in Rabbit." Medical Sciences University of Tehran, 12th Congress of Physiology and Pharmacology (1999).

28. Rezvanipour, Mozafar, Fatemeh Pourzadehhosseini, Reza Malekpour, and Ali Zarabi. "The Effect of Mummy on Some Indices of Wound Healing in Mice." Journal of Kerman University of Medical Sciences 14, no. 4 (2007): 267-77.

29. Dehghan, Mortaza, and Abolghasem Sharifi Faradonbeh. "The Effect of Mummy on the Healing of Bone Fractures." African Journal of Pharmacy and Pharmacology 6, no. 5 (2012): 305-09.

30. Abshenas, Jalil, Reza Kheirandish, and Amin Reza Salary. "Gastroprotective Effect of Mummy on Induced Gastric Ulcer in Rats." Comparative Clinical Pathology 23, no. 2 (2014// 2014): 305-09.

31. Aneesh, T, Mohamed Hisham, M Sekhar, Manjusree Madhu, and T Deepa. "International Market Scenario of Traditional Indian Herbal Drugs-India Declining." International Journal of Green Pharmacy 3, no. 3 (2009): 184.

\section{SAŽETAK}

Cilj: Bitumen je prirodni materijal koji se pojavljuje u usjecima stijena u nekim brdsko-planinskim područjima, a poznat je kao učinkovit lijek za liječenje određenih bolesti. S obzirom na to da ublažava bol, a što se navodi u izvorima tradicionalne perzijske medicine (TPM), ova studija želi razmotriti stajališta mudraca tradicionalne perzijske medicine o bitumenu u kontekstu tradicionalne perzijske medicine. Ovo istraživanje daje odgovarajuće informacije zainteresiranim istraživačima za provođenje kliničkih ispitivanja $i$ vrednovanje terapijskih učinaka bitumena, koje navode izvori tradicionalne perzijske medicine.

Materijali i metoda: Različite baze podataka, uključujući Embase, SID, IRANDOC, IranMedex, Scopus i PubMed, pretražene su pomoću ključnih riječi bitumen $i$ Shilajit. Glavni tradicionalni perzijski medicinski izvori, uključujući Avicennin Canon of medicine, Continens Liber Razesa, The storehouse of medicaments Aghilija, Gift for the faithful Momena Tonekabonija $i$ Measure for medicine koju je napisao Muhammad Akbar Shah Arzani pregledani su pomoću perzijskih ključnih riječi Moomiaii i Mumnaei.

Rezultati: Prema izvorima tradicionalne perzijske medicine, iranski liječnici upotrebljavali su bitumen za liječenje širokog spektra bolesti. Posebno je poznat kao učinkovit lijek za poboljšanje gastrointestinalnih probavnih tegoba.

Zaključak: Bitumen se navodi u tradicionalnim perzijskim medicinskim izvorima kao učinkovit lijek za liječenje širokog spektra bolesti, posebice gastrointestinalnih poremećaja i bolova u kostima. Nedavne studije pokazale su blagotvorno djelovanje bitumena pri zacjeljivanju rana, medutim njegovu bi uporabu u medicinskoj praksi za druge zdravstvene probleme trebalo potvrditi provođenjem kliničkih studija u budućnosti.

Ključne riječi: bitumen; shilajit; tradicionalna perzijska medicina; komplementarna medicina 